\title{
THE POLITICISATION OF ISLAMIC SOCIETY IN POST SOVIET RUSSIA
}

\author{
EMILIA ALAVERDOV \\ Georgian Technical University \\ 77, Kostava str., 0160, Tbilisi, Georgia \\ E-mail address: emily-78@mail.ru \\ ORCID: https://orcid.org/0000-0003-3282-172X
}

\begin{abstract}
Aim. The paper analyses the Islamic revival in Russia in the late $20^{\text {th }}$ century and early $21^{\text {st }}$. This was reflected in the registration of religious communities, the publication of periodicals on Muslim literature, and, in my opinion, most importantly - the construction of mosques and madrassas. It highlights the roles of mosques and madrassas built in the North Caucasus, which later became the theological centers for the spread of Islam and educated youngsters according to their propaganda.

Methods. The study mainly uses an analysis method based on the study of historicism, documents and empirical material. The basis of the source are books, scientific articles, research works conducted by Russian and foreign experts.

Results. The post-Soviet wars (1994-1996 and 1999-2000) in Chechnya contributed to the politicisation and realisation of Islam in this region. In 1996-1999 there were 26 Sharia courts, numerous Islamic parties, charitable foundations and organisations in the republic and, most importantly, structures of Wahhabi organisations (Akaev, n.d.). The process of politicisation gradually turned into organisational formations in Russia in the late 1980s and early 1990s.

Conclusion. The constructive transformation by reinforcing the modernist potentials of Islam has contributed to the real renewal of Russian Muslim societies, which led to the radicalisation of the whole region. The described events have shown that for the last 20 years, the revival of religious Islam was a revival of political organisations and activities, where religion is connected to politics and criminal activities. A small North Caucasian republic immediately turned up at the center of Russia's recent history.
\end{abstract}

Key words: islam, politics, revival, radicalization, Russia, North Caucasus

\section{INTRODUCTION}

fter the collapse of the Soviet Union, religious atheism came to an end; the Islamic factor gained a sustainable tendency and turned into a very dynamic local religion. The process of re-Islmaisation challenged traditional, fundamental and modernist movements. The traditionalists managed to inte-

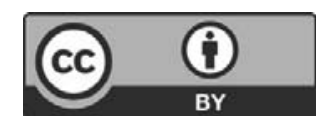


grate into the socio-political system, as, for the fundamentalists, they stood in opposition. The existing disorganisation processes in Russia's Muslims settled regions, the disunity of Muslims and the socio-economic crisis of the 1990s encouraged Islamic radicalization.

At that very time, political groups appeared mainly supporting the ideology of Islamic fundamentalism. In the middle of the 1990s, the fundamental ideology and its specific interpretation of Wahhabi spread among the ultra national organisations.

However, the activation of Islam in modern Russia has both its advantages and disadvantages. The positive side is that it focuses on family and socio-moral values, while the negative can be considered the so-called "political Islam" - the activation of religious-political extremism, which fosters the promotion of religious radicalism in communities and the spread of extremism.

We can conditionally divide Muslims into three groups: a) traditionalists who seek to preserve religious, political, and social institutions in an unchanged form; b) modernists (the same reformists), who are followers of the intelligentsia only, who seek to interpret modern dogmas based on current scientific-technological and social progress in the world; c) fundamentalists as Wahhabis who represent the unemployed crowd.

Russia is a multi-confessional and multinational state. Although it is a Christian state, many Muslims live in the capital itself and throughout its territories. Since the North Caucasus is considered its explosive region the relations with this region are very important, but at the same time very difficult to deal with. This is the case especially when the North Caucasus has been transformed into a permanently politically strained and economically unstable region, where there are armed conflicts that pose a serious threat to the unity and security of the Russian state. The rise of religious extremism in the post-Soviet space requires a very careful and balanced approach.

\section{THE REVIVAL OF ISLAM IN THE POST SOVIET SOCIETY}

In recent decades, Muslim countries have created several influential international organisations that are active throughout the world and as well as in Russia. These organisations are engaged in activities within cultur and religious education. Some of them, through financial means, seek to control the activities of religious communities in Russia, thereby encouraging the socio-political and religious activity of Russian Muslims. The most active international organisations originate from Saudi Arabia, Turkey, Kuwait, and Pakistan.

The revival of Islam dates back to the 1970s and 1980s, but the events of the 1990s were a pure religious renaissance: throughout Dagestan, Muslims began to unite, mosques were restored, and Muslim madrassas, institutes, and universities were opened as well. In January 1990, Muslim clerical rules were established. In the same year, 345 Dagestanis participated in USSR's first Hajj, the number of which has been increasing for years (Khanbabaev, 2007). 
As mentioned above, since the establishment of the Muslim clerical rules and laws in January 1990 and 345 Dagestanians first Hajj, the North Caucasus has become a major threat to Russia. We can say that mostly Dagestan became Russia's explosive region because of the constant instability and tensions inspired by fundamentalists.

In the 90s, religious literature of such classical Islamic writers as Taqī ad-Dīn Ahmad ibn Taymiyyah - a medieval Sunni Muslim theologian and reformer, Ahmad Ibn Hanbal - the founder of one of the four major orthodox legal schools of Sunni Islam, Imam Hasan al-Basri, a Muslim preacher, ascetic, theologian, and mystic began to spread in the North Caucasus, translated into Arabic and other languages. Since the literature was mostly spread in Arabic, young people were encouraged to learn Arabic. There has also been a proliferation of literature written by leaders of religious-political groups and extremists in the North Caucasus such as Bahuddin Magomedov, Magomed Tagayev, Ahmad-Kadi Akhtayev, and others. In this literature, there are calls for the abolition of the constitutional order and the introduction of the Shari'ah, as well as for the collapse of the state security system and the imbalance of public security. They also engaged in the propaganda of war, religious and national persecution, more importantly this literature was circulated illegally (Markedonov, 2010).

The Islamisation of the North Caucasus in the 1980s and the activities of the Wahhabi groups have resulted in security and stability in the region seemingly disappearing. Exact statistics on Wahhabi politics and extremism are not even available today. Adherents of Islamist radicalism have a great influence on all the republics of the North Caucasus except North Ossetia (Vatchagaev, 2005).

\section{THE ESTABLISHMENT OF A NEW IDEOLOGY IN NORTH CAUCASUS}

Wahhabism reached its peak in the second half of the 1990s when they established organisational units, political parties, established contacts with Islamic radical organisations in the continental shores, worked extensively on propaganda, was launched so-called "Verbovka" of youth groups, which led to armed gangs and resulted in armed conflicts against government officials in the North Caucasus, mainly in Dagestan and Chechnya (Malashenko, 2001). These gangs are known to involve young people from disadvantaged areas who are from basic or poor families and have no prospects in life. They originated as the result of the socio-economic problems that as rules are fueling the rise of international terrorism and religious radicalism, and exactly this is the main reason for the fact that young people became the victims of so-called "Verbovka". There are many military camps where, in addition to training young warriors, they teach the Qur'an, which greatly influences their ideology. Then these young men are encouraged to take one-month military training. Those who agree to undergo this training automatically become members of Wahhabi groups. Here it is worth mentioning that youngsters are offered certain material compensation. The young people are under such strong ideological influence that they imme- 
diately obey any orders of their ideological leaders. The Wahhabis lived in tents and were well supplied with food, they were equipped with modern weapons as well. Wahhabis said that they had weapons that could shoot down even a famous "Black Shark" helicopter (Berezhnoi, 2004).

As for Dagestan, the Wahhabi movement there began in the 80s. In 19821984 the authorities of the Soviet Republic of Dagestan suppressed it with the support of the Committee of State Security and the Ministry of Internal Affairs. But as soon as the Soviet Union collapsed, this movement activated itself again. Its founders were B. Magomedov and his brother Abbas Magomedov. They founded the movement as a semi-legal school in the Khasavyurt district of Dagestan, where the brothers at the beginning were teaching Islamic theology. Later, B. Magomedov established contacts with other religious figures in Russia and the Middle East. The prominent Islamic figures frequently visited him and his school and consulted with the students about Islamic ideology and its development in Dagestan and throughout the North Caucasus and, most importantly, the establishment of the Islamic State in the region. B. Magomedov also had close ties with Chechen field commanders. From the beginning of the first war in Chechnya in 1994-1996, he became biased toward more jihadist holy war. He began distributing leaflets where the jihad's direct appeal was heard. In one booklet which was circulated in 2005, there was a certain description of the theological essence of jihad in Wahhabi interpretation and the following writing of an unknown author (Aliev, Arukhov, Khanbabaev, 2007).

The booklet had it that he would like to explain to his Muslim brothers that the Holy War - al-Jihad is one of the main foundations of the religion of Islam. He claimed that it was the only way by which real Muslims get to heaven and find their paradise and find to the satisfaction of Allah (Rizwanullah). In the Qur'an, many Ayats and Hadiths speak of the importance of Jihad and call for it. In the same booklet, the question, whether Jihad and terror have anything in common, has the following answer:

In the sense that terror is now perceived (acts against innocent people), of course, terror goes beyond jihad and no one justifies terror. Furthermore, when we study history, we find that people have been fighting throughout their existence. And what is happening in Chechnya is terror and genocide too, but the Russians declare Chechens who are dwelling in their houses themselves as bandits and terrorists.

\section{THE SPREAD OF RELIGIOUS-POLITICAL EXTREMISM IN DAGESTAN}

The spread of religious-political extremism in Dagestan is divided into four periods:

The first period is seen in 1980-1991 in Makhachkala, a group of Dagestan Wahhabis stormed the building of the North Caucasus Theological Council Mahmud Gakeev, a "mufti" of that time, and dismantled their existing religious structure. It is noteworthy to say that the members of that group were not only Dagestanis, they were following the same religion and ideology from 
the North Caucasus republics, Kyrgyzstan, Turkmenistan and Kazakhstan. Then, in 1991, a group of fanatics tried to break into the Dagestan government building, but the Special Forces succeeded in stopping the event in time.

As for the second period dates back to 1991-1997, when the number of followers of Wahhabism increased sharply. At that time Dagestani researcher Enver Kisriev said that Wahhabism is divided into "poor and rich Wahhabism." He pointed out that the reaction of the nomadic peoples to the worsening postSoviet life exactly appeared in the face of "sacred Islam," in which they saw the justification of poor social conditions and objected to richer governance.

The third period started in 1998 and lasted until 1999 and as we can see it lasted only a year. During this period, Chechen and Dagestan gangs launched an open-armed offensive against Dagestan government structures. The leaders of the group were: Shamil Basayev undisputed leader of the radical wing of the Chechen insurgency, former vice-Prime minister of Chechnya in Maskhadov's government 1997-1998 and Ibn al-Khattab, a Saudi Arabian warlord and field commander whose real name was Samir Saleh Abdullah.

The fourth period can be noticed from 2000 until today.

The radicals can be distinguished in several directions: the inner one which strictly adheres to Islamic rules in their daily lives; and the political - a sect whose aim is to establish a theocratic government even through arms. And we can claim that all of this contributes to poverty and unemployment (Khanbabaev, 2007).

A well-known expert on North Caucasus, Professor Robert Bruceer writes that when Chechen militants invaded Dagestan in 1999, the people of that region were already heavily armed, and when Dagestan law enforcement agencies conducted a voluntary surrender of weapons in 2003, the population brought in from October 1 to December 1: more than 1 tonne of explosives (including large quantities of explosives Hexogen and ammonite), 57 artillery shells and 1 guided missile, 3 anti-tank guided missiles, 6807 grenades, 1256 detonators and much more. According to the Dagestan police, this was only a small part of what people had (Alaverdov, 2013).

Developments in neighboring Chechnya in Dagestan have had a great impact. There were quite a lot of extremists in the border areas of Chechnya who were closely linked to gangs. They often gathered and agreed on their actions and plan to carry out common terrorist acts (Khanbabaev, 2007).

\section{THE CONNECTION OF RELIGIOUS REVIVAL TO THE POLITICISATION OF RELIGION}

The revival of Islam can be considered as the politicisation of Islam; however, it did not manage to unite the religion, since it remains split into the two parts: followers of radical Islam - Wahhabis and Sufis. Generally, Wahhabism, as one of the forms of Muslim fundamentalism, has become very radical in Chechnya and not in Dagestan, as the Wahhabis have been able to form their organisational structures there in a very short period. 
One of the factors contributing to the spread of extremist ideology in Chechnya was the weakness of Orthodox Islam. The process of politicisation of religion began in the fall of 1991 when the legally elected authorities of the Chechen Republic were ousted for refusing to obey Dudaev. The same happened to his legal successor, Mohammad-Haji Garayev. In 1993, he was replaced by Husen-Haji Aslanbekov, a supporter of Dudaev. After Russian troops entered Chechnya, Aslanbekov declared jihad to Russia (Buttaeva, 2009).

It is worth saying that the socio-political situation in Chechnya shows that religious leaders had ambitions to play a major role in the republic's political life. This was evidenced by the fact that Ahmad Kadyrov was elected President of the Chechnya Administration and later the President of the Chechen Republic.

\section{THE UNINFICATION OF SPLIT RELIGION}

Wahhabism became more firmly established during the First Chechen War (1994-1996). Although at that time Islam was split into two sides, and there were even disagreements between them, it was precisely during this war that the Wahhabis came out with the initiative of unification and they fulfilled their task. The split religion was nearly united under the movement of Wahhabi.

By this time, Wahhabism was used as an ideological platform for political goals despite its inherent incompatibilities with traditional Chechen Sufism (Vatchagaev, 2005). Foreign Wahhabi influence thus led to enmity between proponents of increased political and cultural orientation on Saudi Arabia and other Islamic regimes, and those who aspired to preserve the local form of Islam and the traditional, indigenous foundations of government. Furthermore, for the Chechen society Wahhabism constituted an artificially adopted international religious-political ideology, which severely compromised the rudimentary Sufi traditions of ancestral worship, veneration of holy sites and sainthood (Erudition, 2003). Supported by Dzhokhar Musayevich Dudayev the first President of the Chechen Republic of Ichkeria, Arbi Barayev and Abdul-Malik Mezhidov these last two were prominent warlords self-proclaimed judges in military Sharia tribunals (Akaev, 2014). It was under Sh. Basayev's leadership that a militant group invaded Dagestan in 1999, where he was badly wounded. Dz. Dudayev before being killed in a special operation on July 10, 2006, awarded Sh. Basayev the title of colonel and appointed him as head of the squad. This "Colonel" had implemented numerous terrorist acts, including such horrific and dreadful acts as the Beslan school siege taking 1,100 people as hostages among them 777 children and having killed here more than 335 people. Here we have to say that in 2004, the US announced the group of Sh. Basayev as a terrorist group and "blacklisted" it (Curtis 2002).

It is impossible to talk about the events in Chechnya without mentioning the well-known al-Khattab, whose activities were mainly related to the establishment of specialised camps, where he trained professional "fighters of Islam". Al-Khattab was a well educated Saudi Arabian man who preached Wahhabism and the Holy 
War; he was fluent in English, Russian and Pashto, which helped him to establish contacts between international terrorism structures and Chechen militants.

One of the key factors of the radicalisation of Islam in Chechnya was that Chechen youth had to receive Islamic education at Wahhabi training centers in the Middle East (Akaev, 2014).

\section{THE INVASION OF DAGESTAN}

The not least important factor is the armed invasion of Wahhabi activists, led by Sh. Basayev and U. Al-Khattab from Chechnya to Dagestan in 1999. These two thought that they would be welcomed by Dagestani people, however, they were mistaken and it did not happen.

Wahhabi ideology was supported by financial support from the Middle East. The so-called sponsors of Wahhabi spread in the North Caucasus region are non-governmental and Islamic organizations. "Jihad activities" in Chechnya and Dagestan are funded through various Middle East and Western banks.

As we have already noted, in the late 80 s illegal groups appeared in certain areas of Dagestan and the Republic of Chechnya, adherents of the religiouspolitical fundamentalism of Islam, which later became known as Wahhabism. This has resulted in a wave of disintegration processes in the region and has been contributed to several factors: a) the spread of Islamic fundamentalism - Wahhabism's extremist direction, b) political, cross-border financial and military aid, and c) aggressive nationalism and separatism in the region.

The well-known events in Dagestan in August-September 1999 have put the region under the Wahhabism real danger, which under the form of Jihad threatens not only the North Caucasus republics and their populations, but also the Russian state (Kohlmann, 2001).

\section{POTENTIAL OF ISLAM IN RUSSIA IN THE LATE $19^{\mathrm{TH}}$ EARLY $20^{\text {TH }}$ CENTURIES}

At the same time, it is noteworthy to highlight the genius of some scholars who have been able to determine the fundamentalist tendency of the Islamic movement. In pointing to the parallel between the revival of Islam and the Christian Reformation, S. Huntington noted that both hese processes are a reaction to the corruption of the existing institutions and their stagnation; these processes represented the push and urge to return to more sacred and demanding forms of religion; preached discipline and order; these processes drew attention and got the support of modern and dynamic middle class society; different trends show the tendency to have two main directions - Lutheran and Calvinist, Shiite and Sunni fundamentalism; there are also parallels between Jean Calvin and Ayatollah Khomeini and the theological discipline that each of them wanted to establish in his community. The most important is that the central spirit of both the Reformation and the Islamic revival is fundamental reform. 
Should one pay attention to the origins of genesis and the development of modern social speeches, we would have to acknowledge S. Huntington's insistence that the Islamic revival is linked to the internal sources of long-standing usurpation and abuse of power. The clan ruled by Kh. Mubarak and M. Gaddafi is far beyond the frame of the Qur'an and Sunnah, which clearly states the need for democratic principles of governance (Sura "Ash-Shura' 'Council"). The long rule of one clan should be regarded as a negative event of society, in which the society is confused with political, and most importantly, economic rights. Thus, the revolutionary movement of Islamic countries is conditioned by the existence of corrupt regimes, which is incompatible with the modern image of Muslims. Of course, they have the right to dismiss any socio-political system that does not suit society. The Qur'an states that if he is the head of state and does not strive for the welfare of the people and spread injustice, perish the crop, destroy the people and the society, Allah does not love such a person. Allah does not love injustice! (Alaverdov, 2013).

It is a matter of law that in a society whose members are followers of a monotheistic religion, the existing social and political processes are, as a rule, initially manifested in a cultural context, and then moved to the social and political realm. In such a society, religion is the soul of people who can become a force for organising both progress and regression.

It is important to note that the Islamic revival process was revealed long before S. Huntington's theory. While much research has been devoted to the principles of modernisation in Turkish society at the beginning of the 20th century, the theme of Jadism, the Muslim renewal in Russian society, has attracted attention and concern only in the last decades of this century. The thesis that this religious-social movement is a modernisation of the Muslim community within the framework of Islam is more substantiated.

The fact that the social upbringing of the Russian Muslims mentioned above in the Islamic intelligentsia is viewed as an educational process is in line with S. Huntington's theory which states that Islamists pay great attention to the organisation of Islamic schools as well as the influence of religion on public schools. Islamic groups created an Islamic "civil society" that duplicated, surpassed, and often replaced, weak institutions of secular social order.

\section{CONCLUSION}

Thus, the Islamic revival scenario of the Muslim countries, beginning in the late 19th century, was completely implemented in the 19th-20th century.

The theologians of the twentieth century, saw the progressive nature of modern Islam in its secular scientific justification for ensuring the harmonious development of man. They believe that moral and educational evolution is the main tool of social reforms.

So, we have every reason to speak boldly about the progressive development of education in the above-mentioned region at the beginning of the last 
century, under the auspices of national intelligentsia and clergy. New educational institutions were combining religious and secular education. There is no doubt that the progressive clergy of the region were precisely in charge of establishing democratic and civilised educational programs.

The successful beginning of the educational process based on the Islamic religion of the people of North Caucasus also confirms the fact that the number of educated people has greatly increased, people have mastered the crafts and professions which marked the beginning of the modernisation of the region's economic sphere.

This proves that there are progressive and constructive forces within the Muslim community that can facilitate the transition of a society to the contemporary technological space. Under modern conditions, this is reflected in the cooperation between the North Caucasus communities and the Russian state structures. There is also an ongoing educational activity among young people on the formation of social immunity of tolerance and extremism. The outlines of the joint work of Christian and Muslim clergy with a view to respect for one another and other ethnicities and confessions are drawn more clearly.

\section{REFERENCES}

[1] Akaev, V. (2014). Religious and Political Elites in the Northern Caucasus: Formation, Ideological, Ideological Contradictions, and Practical Opposition. Religion in Society, Central Asia, and the Caucasus, 15 (1), 81-83.

[2] Aliev, A, Arukhov, Z, Khanbabaev, K. (2007). Religious - Political Extremism and Ethno-religious Tolerance in the North Caucasus. Moscow.

[3] Akaev, V. (n.d.). Religious-Political Conflict in the Chechen Republic of Ichkeria, CA\&C Press AB, Publishing House (Sweden).

[4] Alaverdov, E. (2013). Islam Factor in History and Modern Russia, Ph.D. Thesis, Georgian Technical University, Tbilisi, Georgia.

[5] Berezhnoy, S. (2004). Islamski fundamentalism na Yuge Rossii [Islamic Fundamentalism in the South of Russia]. Monograph, Rostov-on-Don.

[6] Buttaeva, A. (2009). Islamskoe vozrozddenie v Rossii [Islamic Revival in Russia]. Bulletin of the Dagestan Scientific Center of the Russian Academy of Sciences, 36.

[7] Curtis, G. (2002). Involvement of Russian Organized Crime Syndicates, Criminal Elements In The Russian Military, And Regional Terrorist Groups In Narcotics Trafficking In Central Asia, The Caucasus, And Chechnya. Washington, D. C.: Federal Research Division, Library of Congress.

[8] Erudition - Russian Electronic Library Report. (2003). Report: Islam and Politics in the Chechen Republic.

[9] Kohlmann, E. (2001). The Legacy of the Arab-Afghans: A Case Study. Washington D.C.: International Politics Honors Thesis, Georgetown University, Edmund A. Walsh School of Foreign Service.

[10] Khanbabayev, K. (2007). Islamskiy radikalizm na Severnom Kavkaze. Ideologiya, tseli, puti finansirovania [Islamic Radicalism in the North Caucasus. Ideology, Goals, Ways of Financing]. Journal Free Thought, 3.

[11] Malashenko, A. (2001). The Islamic Reference of the North Caucasus. Carnegie Moscow Center Moscow.

[12] Markedonov, S. (2010). Radical Islam in the North Caucasus: Evolving Threats, Challenges and Prospects. A report of the CSIS and Eurasia Program.

[13] Vatchagaev, M. (2005). The Role of Sufism in the Chechen Resistance. Erudition - Russian Electronic Library Report. Report: Islam and Politics in the Chechen Republic. 